The fact that the British Government has given a considerable grant for a limited and short period in order to meet part of the expense of an international fishery investigation does not, unfortunately, enable us to claim that we have a " marine biologist to the Government." The Government gives various grants to enable special pieces of scientific work to be carried out, but that does not constitute the recipients Government officials.

Dr. Allen reminds us that a marine biologist has been recently appointed inspector of fisheries. Fortunately that is no new thing. The list in the past includes Huxley and Frank Buckland, and we hope that all our inspectors of fisheries are competent biologists-but they are H.M.'s "Inspectors of Fisheries."

The Government grant to the Marine Biological Association goes to no Government official. The cover of the current number of the Journal of the Marine Biological Association announces that "The Association owes its existence and its present satisfactory condition to a combination of scientific naturalists, and of gentlemen who, from philanthropic or practical reasons, are specially interested in the great sea-fisheries of the United Kingdom." This is no Government institution.

One of the conditions attached to the annual grant from the Treasury was that space at the Plymouth Laboratory should be placed at the disposal of any competent investigator deputed to carry out investigations into fishery questions. None of the Government fishery departments (England, Scotland, Ireland) have, however, availed themselves of this condition. Where, then, is the "Government marine biologist "? The Writer of the Note.

\section{Learned and Unlearned Societies.}

Mr. Basset's letter (p. 437) is of importance in giving authoritative evidence of what goes on behind the scenes. It was only a matter of suspicion with me that the benevolent rejectors sometimes knew even less about the subjects of the papers than the authors themselves. But the remedy proposed by Mr. Basset is, I fear, a very unsatisfactory one. Just the same sort of thing can and does occur elsewhere. The only right and proper course seems to be that indicated by Mr. Buchanan. It would be enormously to the advantage of an old-established institution, and to its members, even though there might sometimes be some counteraction by the admission of poor matter. But it is not necessary to repeat here Mr. Buchanan's argument, which was very strong and full of common sense.

March I3.

\section{A Plea for Good English.}

I BELIEVE the phrase that "language was given us to conceal our thoughts" only holds good in diplomacy, and it may therefore be reasonably expected that a professor of science should endeavour to teach his pupils to express themselves in clear, concise and literary English. The German language lends itself to a process known as wordbuilding, and for aught I know to the contrary, the word "Schwefelkohlenstoff" may be good, literary German. But this process is altogether foreign to the genius of the English language, and I cannot imagine a more barbaric or misleading conglomeration of verbiage than the phrase " chalk-stuff-gas." Chalk is popularly associated with lime, or, to speak more accurately, with calcium, and to call a substance " chalk-stuff-gas" which does not contain an atom of calcium appears to me a misuse of language, especially as $\mathrm{CO}_{2}$ can be prepared in various ways without using any substance containing calcium, or what is popularly known as " chalk" or "lime." It seems to me that it would be difficult to invent a more suitable phrase than "carbon dioxide," since it expresses in terse and pointed language the chemical composition of the gas.

Alassio, March 9.

A. B. BASSET.

\section{Zoological Nomenclature.}

ON p. 200 of your issue of December 31, 1903, just arrived, in a review by "W. T. B." I note an allusion to my " curious illustrations of zoological nomenclature," and it is stated that my "new name" (which, by the way, was proposed in I899!) " is given to a genus the type of which appears, according to the rules of Linnæus himself, to be also the type of the Linnæan genus Cimex."

Where sir are these "rules of Linnæus himself" in which the fixation of types is set forth? I was under the impression that we were indebted to Fabricius for these in dispensable aids to zoological nomenclature, and I would be grateful for the reference to Linnzeus.

Your reviewer's remark on Cimex contains an er:or; "lectularius" is not and cannot be the type of Cimex, Linn., (I) because it does not conform to the description of that genus as set forth by the founder. Moreover, if the type be worked out historically, "lectularius" is equally invalid; the first discerptor was Fabricius, who, in a perfectly straightforward manner, removed our species from Cimex to form a part of his new genus Acanthia. This effectively prevents lectularius from ever appearing as the type of Cimex, and it is a fact well known to the students of the Rhynchota.

Further, lest it might be thought that the proper generic name of lectularius is Acanthia, let me mention that in I797 Latreille restricted the latter to " littoralis " and its congeners, and "lectularius" was again shut out, the way that, so far as my knowledge then went, I was justified in proposing a new name. However, since then I have acquired a somewhat rare book, the "Hemiptera Sueciæe" ( 1829 ), the authorship of which is usually ascribed to Fallén, but is mentioned as Johannes Petersson for p. 141, where "Clinocoris" is proposed, and I willingly, and, indeed, inevitably, retire in favour of this for the unfortunate and so long homeless "bed-bug." My previous ignorance of this was shared apparently by everyone since the first announcement of the name (as applied to lectularius).

With regard to the "curious illustrations of zoological nomenclature," I would refer "W. T. B." to the witty and able "Zoological Nomenclature. Remarks on the Proposed International Code,' by 'T. R. R. Stebbing, in the Zoologist for October I5, 1898,2 , pp. 423-8. As the reverend karkinologist remarks, " no possible harm is done if we do leave to the polished scholar some little occasion for chuckling over us untutored sons of science."

G. W. Kirkaldy.

Department of Agriculture, Honolulu, H.I., January 26.

Mr. KIRKALDY's remarks about the type of the Linnæan genus Cimex are a quibble, to which it is sufficient reply to point out that in the passage which he quotes and attempts to ridicule it was not stated that Cimex lectularius was made the type of the genus by Linnæus.

Although the selection of one species of each genus as the type is of later date than Linnæus, several of the Linnæan genera are clearly founded on a particular species in each case. Thus, to take familiar forms, Equus is named from the horse, and it is therefore correct to say that $E$. caballus is the type of the Linnæan genus Equus. Similarly Bos taurus is the type of Bos, and Canis familiaris of Canis. Similar cases are rare amongst invertebrate animals, but Cimex is an exception, for the generic name was taken from a species in the Linnæan genus that was called Cimex in classical Latin. The only species that can be clearly identified with the Latin name appears to be $C$. lectularius, Linn.

This, however, has been disputed-what opinion has not? -by a few amongst the very many writers who have treated the question of Cimex and Acanthia, so another reason may be given for regarding $C$. lectularius as the type of Cimex. The rule of Linnæus, quoted below, was that if a genus be divided, the commonest and best known species should be retained under the original generic name. There can be no question that $C$. lectularius is by far the best known species of the genus.

The "rules of Linnæus himself" were printed in his "Philosophia Botanica," and quoted by Agassiz in the introduction to the "Nomenclator Zoologicus." These rules have always been regarded as authoritative by both botanists and zoologists, and should in any case be consulted when Linnæan genera and species are concerned. The two following rules apply in the present case :-

242. Nomen genericum Antiquum antiquo generi convenit.

246. Si genus receptum, secundum jus naturae et artis

No. 1794 . VOL. 69] 